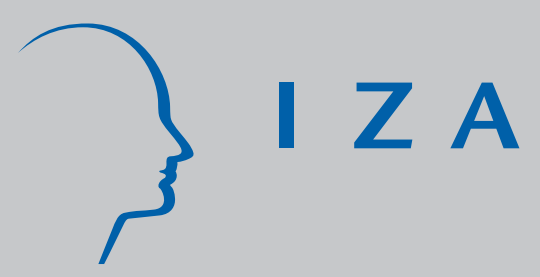

IZA DP No. 3454

The Economics of Communist Party Membership:

The Curious Case of Rising Numbers and

Wage Premium during China's Transition

Simon Appleton

J ohn Knight

Lina Song

Qingjie Xia

April 2008 


\title{
The Economics of Communist Party Membership: The Curious Case of Rising Numbers and Wage Premium during China's Transition
}

\author{
Simon Appleton \\ Nottingham University \\ John Knight \\ Oxford University \\ Lina Song \\ Nottingham University and IZA \\ Qingjie Xia \\ Peking University
}

Discussion Paper No. 3454

April 2008

IZA

P.O. Box 7240

53072 Bonn

Germany

Phone: +49-228-3894-0

Fax: +49-228-3894-180

E-mail: iza@iza.org

Any opinions expressed here are those of the author(s) and not those of IZA. Research published in this series may include views on policy, but the institute itself takes no institutional policy positions.

The Institute for the Study of Labor (IZA) in Bonn is a local and virtual international research center and a place of communication between science, politics and business. IZA is an independent nonprofit organization supported by Deutsche Post World Net. The center is associated with the University of Bonn and offers a stimulating research environment through its international network, workshops and conferences, data service, project support, research visits and doctoral program. IZA engages in (i) original and internationally competitive research in all fields of labor economics, (ii) development of policy concepts, and (iii) dissemination of research results and concepts to the interested public.

IZA Discussion Papers often represent preliminary work and are circulated to encourage discussion. Citation of such a paper should account for its provisional character. A revised version may be available directly from the author. 


\section{ABSTRACT \\ The Economics of Communist Party Membership: The Curious Case of Rising Numbers and Wage Premium during China's Transition ${ }^{1}$}

Why is it that, as the Chinese Communist Party has loosened its grip, abandoned its core beliefs, and marketized the economy, its membership has risen markedly along with the economic benefits of joining? We use three national household surveys, spanning eleven years, to answer this question with respect to labour market rewards in urban China. We conceptualize individual demand for Party membership as an investment in "political capital" that brings monetary rewards in terms of higher wages. This wage premium has risen with the growing wage differentials associated with the emergence of a labour market and the continuing value of political status in the semi-marketized transitional economy. However, a demand-side explanation does not explain the fact that the wage premium is higher for the personal characteristics that reduce the probability of membership. We develop an explanation in terms of a rationing of places and a scarcity value for members with those characteristics.

JEL Classification: J31, J40, J71, P20, P30

Keywords: China, Communist Party, labour market, economic transition, wages

Corresponding author:

Lina Song

School of Sociology and Social Policy

University of Nottingham

Nottingham, NG7 2RD

United Kingdom

E-mail: lina.song@nottingham.ac.uk 


\section{Introduction}

A paradox of the reform process in China is that, as the Chinese Communist Party (CCP hereafter) has loosened its grip on the economy and seemingly abandoned its core beliefs, its membership has risen markedly along with the economic benefits from joining. Karl Marx famously envisaged the state "withering away" in the advanced stage of communism. Outsiders have often made a similar assumption about the Communist Party withering away with marketization. In China, the Party exercised considerable control over pay and promotion during the planning period (Groves et al., 1995). However, this control has been eroded, so the naïve assumption would be that the wage premium to Party membership should fall. This in turn should reduce recruitment among opportunistic would-be members, while idealists may be repelled by the Party's abandonment of its core beliefs. Instead, membership has expanded from 3.8\% of China's population in 1978 to $5.2 \%$ in 2002. In June 2002 , the CCP had $66 \mathrm{~m}$ members, $5.2 \%$ of the total population, making it the largest political organization in the world. In this paper, we show that the wage premium associated with being a member has risen over time.

We can distinguish several explanations for the wage premium. The Party may use its influence to give preferential treatment to its members in order to ensure their loyalty. As Walder (1995, p.323) states "career rewards for the politically loyal has been one of the foundations of Communist Party rule”. Li and Walder (2001) analyse access to elite administrative positions and show how members who join the Party early in their career appear to benefit from its patronage. There can also be less principled rent-seeking, with members using their political power to promote their own interests. More generally, membership may give access to contacts that are useful for a career and thus increase the individual's social capital. The "New Class" theory of Djilas (1957) argued that, although communist parties might have come to power with the aim of promoting egalitarian societies, in practice they gave rise to a "redistributive elite". These explanations imply a causal link from membership to wages: that membership brings economic benefits. However, it is also possible that the relation is non-causal. Standard empirical models of wage determination omit variables - loosely referred to as "ability" - that may be associated with both Party 
membership and higher wages. The Party has on occasion recruited the most productive workers in an enterprise or, if it wants to fill a cadre post with a particularly promising individual, may recruit that person at the same time as appointing them to a post.

How would we expect economic reform to affect these relationships between Party membership and wage differentials? We have already referred to the prediction that the diminished role of the Party in the economy should imply a lower economic return to membership during the transition. During the planning period, as Groves et al. (1995, p.876) state: "the Communist Party ... functioned more or less as the personnel department of this enormous corporation, maintaining dossiers and tracking managerial careers.” The Party approved promotions and certain posts of responsibility were reserved only for its members. Urban reforms in the 1980s largely removed the formal role of the CCP in determining promotions within state-owned enterprises (SOEs hereafter). The Party still approved the appointment of enterprise managers, but these managers then had autonomy over promotions within the enterprise. Greater managerial autonomy within the SOE sector, coupled with an expansion of private sector, might be expected to lead wages to be set according to worker productivity rather than political loyalty. Thus Nee (1989) hypothesised that membership should lose its privileges as marketisation raised the returns to productivity (human capital) and reduced the redistributive power of the Party.

This hypothesis is contradicted by the evidence of an increasing wage premium on CCP membership. An alternative hypothesis is that marketisation can increase the private value of membership because productive, personal or power relations can now attract monetary rewards, a symptom of which is the general rise in income inequality and the widening of wage structures. Prior to reform, there was little job mobility and wages were set largely by administrative pay scales. With reform, managers have the power to vary wages. This enables wages to vary across individuals, whether it is due to productivity, particularism or social capital. If the CCP premium merely results from selectivity or reverse causality, then reforms which increase the returns to productivity could also increase the premium. Alternatively, the reforms may allow more scope for rent seeking as there is more scope for wages to differ within and between enterprises. Marketisation may increase the value of information and 
networks. Party membership can have a "sheepskin" effect, signalling the presence of certain characteristics. Members may use their networks to find information on job opportunities. This informational and network role of the Party may be particularly valuable during transition, when alternative information systems are incomplete and unreliable.

In this paper, we use household survey data to analyse the determinants of CCP membership and the associated wage premium. The data come from the China Household Income Project (CHIP) surveys, designed by a team of international scholars, including the authors, and researchers at the Chinese Academy of Social Sciences. There are two main attractions of the CHIP surveys for this work. First, they provide a very detailed measurement of income and labour supply. Second, the surveys are large-scale and designed to be nationally representative (although we use only the urban component). The CHIP surveys draw subsamples of households from the annual national household income survey of the National Bureau of Statistics (NBS), covering 10 out of 31 provinces in 1988, 11 in 1995 and 6 in 1999. A limitation of our samples is that only households with urban registration (hukou) are included. The NBS surveys of urban China exclude most rural-urban migrant households, since these are denied urban hukou.

\section{The empirical literature on the wage premium for CCP membership}

There have been many studies of wage determination or income inequality in China that include estimates of the premium for CCP membership. However, only a few papers are devoted to the topic - notably, Morduch and Sicular (2000), Bian and Logan (1996), Lam (2003), Liu (2003) and Li et al. (2007). A related body of work is that by Walder on the effects of CCP membership on attainment of elite occupations (Walder, 1995; Li and Walder, 2001). We focus primarily on results for urban China.

Most empirical studies take CCP membership as exogenous and do not allow for the fact that members may differ from non-members by virtue of unobserved, pre-existing characteristics that are related to earnings ("ability"). The three studies that allow for endogeneity (or, 
equivalently, selectivity) reach contradictory results - one found the problem insignificant; one found it biased the OLS estimates downwards, and the third found an upwards bias. The conclusion that OLS estimates were biased downwards was drawn by Liu (2003), who used the CHIP 1988 and confined his analysis to households containing father-son pairs of workers. Using the father's education as an instrument for the son's CCP membership, he found the wage premium rose from $11 \%$ when estimated in OLS to $51 \%$ after instrumenting. Lam (2003) took a similar approach to analysing a survey of workers in Shanghai in 1996. Using whether the father was a CCP member to identify the impact of Party membership, she found no evidence of a selectivity bias to OLS estimates, with the selectivity correction being insignificant. Conversely, Li et al. (2007) used a survey of Chinese identical twins in 2003. They also found a wage premium of around $11 \%$ from OLS analysis, but it disappeared to almost zero when estimated using a within-twin-pair fixed-effects model. They concluded that the premium is purely a return to unobserved ability and ended their paper with a paean to the "high quality" of CCP members.

It will be seen that our results are closest to those of Lam (2003): we do not find selectivity to be a serious problem. The conflicting results in the literature may reflect data differences - for example, Li et al. (2007) found no CCP wage premium for younger workers even using OLS. There may also be problems with the instruments used - parental Party membership and sometimes other aspects of parental occupation. Twin estimates have their own methodological limitations. Specifically, they may be biased downwards owing to measurement error - a problem normally solved by instrumenting in the literature on returns to education but this solution was not available to Li et al. (2007). In the context of education, it has been argued that measurement error may render within-twin-pair fixed-effects less reliable than OLS (Ashenfelter and Krueger, 1994).

The studies that consider selectivity do not examine changes in premiums over time. Of the studies looking at time trends in the observed wage premium, some reach strong conclusions based on very limited data. For example, Morduch and Sicular (2000) argue that Party members have benefited in particular from the reform process, but base their conclusion on only one rural country in northern China and cover only the short period 1990-93. Xie and 
Hannum (1996) argue that the premium does not change with economic growth, but base their analysis purely on the finding that the CCP wage premium as estimated in the CHIP 1988 survey does not vary with the city-level economic growth rate over the period 1985-88. Most studies that estimate observed income differentials by CCP membership over time find they increased in recent years. Bian and Logan (1996) find a rise in the premium for Party membership when analysing data from Tianjin spanning 1978-93. Wu (2006) uses life histories and finds a significant effect of CCP membership when modelling income per capita in urban China in 1996. Since Wu also controls for 1986 income, this result implies that members enjoyed faster income growth between 1986 and 1996, ceteris paribus. Knight and Song (2003), using the CHIP 1988 and 1995 surveys, estimate that the CP premium doubled, from 4.2 to $9.0 \%$.

Aside from looking at changes over time, a second focus of this paper is how the wage premium for CCP membership varies with other determinants of earnings. Lam (2003) finds a premium in SOEs and collectives, but not in private enterprises. Bishop et al. (2005) use the CHIP 1988 and 1995 to estimate the premium using quantile regressions. For 1995, they find the premium falls as the earnings quantile rises, implying that membership has a larger effect on workers with unfavourable unobserved determinants of earnings.

\section{Framework: the economics of Communist Party membership}

In Western political systems, parties compete against each other for power and so are relatively open in admitting new members, since these provide funds and personnel for this political competition. For the individual, joining a party may be seen as primarily marking an ideological affiliation and membership is unlikely to have a direct effect on one's career or economic circumstances. By contrast, in China, the CCP has a monopoly on political power and historically has maintained its grip on power by virtue of a loyal membership, carefully vetted on admission and subject to scrutiny thereafter. Moreover, its dominant position and its occupation of important administrative positions imply that joining can bring real economic benefits to the individual. 


\section{The Party's screening of prospective members}

Joining the CCP requires two decisions: that the individual decides to join and that the Party decides to admit the individual. We refer to the former decision as the individual's demand for membership and the latter decision as reflecting the Party's screening of members. The process has three broad stages. First, the individual must make a formal application; although Guo (2002) states that the initial approach nonetheless usually comes from the Party. Second, there is a period of observation and training. The individual must participate in study sessions and community service while subject to daily monitoring. One or two CCP members act as liaisons (lian xi ren) while background checks on the applicant are performed and opinions sought from other members. Third, after admission there is a one-year probationary period. Even after their probation, members are subject to a degree of scrutiny by the Party and can be expelled if they fail to attend meetings for six months without good reason. Individuals' decisions to join are essentially irreversible, with loss of Party membership being seen as very serious. $^{2}$

The Party looks for recruits who are committed to its values and will participate actively in politics. Beyond this, it is possible to discern several important overall trends in the screening criteria (Bian et al., 2001). Prior to 1949, revolutionary ideals were the qualities sought in new members but class background was often used as a loyalty filter. Similar criteria existed in the planning period, 1950-78. Parental membership of the CCP was added to class background as a screen for loyalty. However, political commitment and participation was also required. Owing to the key role of the Party in administering the economy and the machinery of government, membership became increasingly urbanized and professional competence grew in importance. Exemplary workers were often targeted for recruitment. The Cultural Revolution represented a backlash against increasing managerialism, and during this period of discord intellectuals were regarded with suspicion. The reform period, from 1979 onwards, saw a marked change in the criteria. With the prioritization of economic growth, the CCP sought to recruit economically productive members. Education replaced class background as an explicit criterion. In 2001 private business people were openly invited to join: 
entrepreneurs were now acknowledged as part of the "advanced productive forces" that the CCP was now supposed to stand for. In summary, the CCP's screening criteria have an important effect on who joins, although the particular criteria used have changed markedly over time.

\section{The individual's demand for Party membership}

While ideological reasons and "commitment" may have led some to join the CCP early on, the level of commitment is likely to have diminished as the realities of life under Communist rule became apparent. Political campaigns such as the mass mobilizations during the Cultural Revolution can be seen in part as an attempt to recreate the ideological fervour that had driven Party members. But in the reform period, it seems increasingly unlikely that people joined the CCP for ideological reasons as the Party gradually abandoned most of the ideology that was its raison d'etre. Traditional Communist precepts were overturned by contrary slogans such as that of Deng Xiaoping that "to get rich is glorious". After over twenty years of reform, this culminated in the CCP lacking a clear ideological basis. ${ }^{3}$

A survey of university students in Shanghai in 1988 suggested widespread cynicism about the reasons people became members (Guo, 2002). Students in 18 universities were asked about their friends' motivations for joining. $49 \%$ of respondents picked the response that "In reality they want a "Party card" which they can use as capital to receive future benefits". Only 4\% chose the option "They believe in Communism and want to make a contribution". Indeed, the growing perception that membership provides material benefits and is a vehicle for opportunistic careerism may have deterred more idealistic people from joining.

Instead, joining the Party can be viewed as being based on a cost-benefit analysis of private material advantage. Just as education is regarded as an investment in human capital, CCP membership can be regarded as an investment in what is sometimes termed political capital. The costs of membership are not primarily financial - membership dues are low. The costs may be largely up front - subjecting oneself to an onerous screening procedure. Subsequent costs take the form of time devoted to CCP activities and submission to scrutiny and 
discipline. However, membership may bring various forms of benefit: additional income, additional perks, higher status and greater power or influence. The non-economic benefits can be ends in themselves as well as providing means of obtaining economic benefits.

\section{The selection process}

The selection process can be formalized as follows. Let $P^{*}$ represent the unobserved net utility placed on CCP membership by an individual and $V^{*}$ represent the unobserved net utility to the Party of the individual's membership. We postulate the index functions

$$
\begin{aligned}
& P^{*}=\mathrm{a}^{\prime} \mathrm{X}+u \\
& V^{*}=\mathrm{b}^{\prime} \mathrm{Z}+v
\end{aligned}
$$

where $\mathrm{X}$ is a vector of personal characteristics influencing individual preferences, $\mathrm{Z}$ is a vector of characteristics that the Party values in its members, and $u$ and $v$ are error terms.

If $P^{*}$ is positive, the person wants to join the Party, and if $V *$ is positive, the Party wants him to join. Where $M$ is a dummy variable indicating Party membership, the decision rule is

$$
\begin{aligned}
& M=1 \text { iff } P^{*}>0 \text { and } V^{*}>0 \\
& M=0 \text { iff } P^{*}<0 \text { or } V^{*}<0 .
\end{aligned}
$$

If $u$ and $v$ have the standard properties, the probability of a person wanting to join is $\Phi(\mathrm{a} X)$ and the conditional probability of being chosen is $\Phi\left(b^{\prime} \mathrm{Z}\right)$, where $\Phi($.$) is the standard normal$ cumulative distribution function. On the assumption of independence between these choices, the probability of observing that a person belongs to the CCP is $\Phi\left(\mathrm{a}^{\prime} \mathrm{X}\right) \Phi\left(\mathrm{b}^{\prime} \mathrm{Z}\right)$. In the absence of rationing, only $\Phi\left(\mathrm{a}^{\prime} \mathrm{X}\right)$ is relevant: all the parameters in $\mathrm{b}^{\prime} \mathrm{Z}$ except the constant term are zero. Identification of the separate equations is problematic if both decisions are influenced by the same set of variables $(Z=X)$. In the empirical analysis of Section 4 , we use a simple binary probit to model whether urban workers are Party members:

$$
\begin{aligned}
& M^{*}=\mathrm{c}^{\prime} \mathrm{X}+\varepsilon \\
& M=1 \text { iff } M^{*}>0
\end{aligned}
$$


The significant coefficients $\mathbf{c}$ in the estimated equation must be examined for consistency with screening (CCP preferences) and demand (personal preferences) interpretations.

Some insight into these alternative interpretations of the determinants of CCP membership can be gained by looking at how the wage premium for membership varies with individual characteristics. Wage functions can be estimated separately for Party members and non-members:

$$
\begin{aligned}
\ln Y=\mathrm{d}_{\mathrm{p}}{ }^{\prime} \mathrm{Q}+s_{p} & \text { if } M=1 \\
=\mathrm{d}_{\mathrm{n}}{ }^{\prime} \mathrm{Q}+s_{n} & \text { if } M=0
\end{aligned}
$$

where $\ln Y$ is the $\log$ wage and $s$ is the error term. The wage gains from membership are thus:

$$
E(\ln Y \mid M=1)-E(\ln Y \mid M=0)=\left(\mathrm{d}_{\mathrm{p}}-\mathrm{d}_{\mathrm{n}}\right)^{\prime} \mathrm{Q}+E\left(s_{p} \mid M=1\right)-E\left(s_{n} \mid M=0\right)
$$

The differences in vectors of coefficients $d_{p}$ and $d_{n}$ can then be compared with common variables in the vector $\mathrm{c}$ in the Party membership equation.

If membership is primarily demand-determined, one might expect a correspondence of $c$ and $\left(d_{p}\right.$ $d_{n}$ ): characteristics that increase the economic benefit from membership also increase the probability of membership. However, such a pattern will not necessarily be observed in a rentseeking equilibrium. A higher benefit (rent) for members of one type may induce more people of that type to join the Party, driving the average benefit for them down to equal the cost of membership. However, a positive correspondence between $c$ and $\left(d_{p}-d_{n}\right)$ may arise if the costs of membership to individuals are heterogeneous. Some individuals are likely to be more averse to the non-pecuniary costs: higher wage benefits will be required to induce such people to join. Hence one will tend to see higher wage premia for groups with higher rates of membership.

Conversely, if membership is determined by the Party's screening - a rationing process, rather than demand - one might expect a negative relation between $c$ and $\left(d_{p}-d_{n}\right)$. Suppose membership provides rents that only members of a certain type can compete for. If the Party restricts the numbers of members of one type, there will be less competition for the rents available for this type and thus higher average rents. For example, suppose Party membership is required for lucrative posts of responsibility within two groups of workers (say, employees at factories A and 
B). If the Party acts to restrict the supply of workers of one type (say, at factory A) who become members, then the lucky few who are members will have a greater chance of being given a lucrative post. In this instance, lower probabilities of being a member will be associated with higher returns to membership.

Another issue arising in the paper concerns the interpretation of the apparent increase in the wage premium. Preliminary findings indicate that a premium exists and that it has been rising over time. It is possible that unobserved ability is a determinant of both CCP membership and wages, and that both of these relationships have become more important over time, i.e. the Party has become more meritocratic and merit has been more rewarded in the labour market. This could explain the apparent premium and its rise over the years.

These problems can be viewed as arising from correlations between the unobserved factors, $\varepsilon$, which determine Party membership and those unobserved factors, $s$, that determine wages. Consistent estimates can be dealt with using the sample selection correction suggested by Heckman (1979). This requires that we have instruments for membership: variables that are closely correlated with $M$ but are not direct determinants of wages. In the data that we have, information on parental CCP membership would appear a priori to be a good instrument. A second way of correcting for this problem is to use panel data. If the unobserved determinants that cause biases are time-invariant, then they will be removed by using a fixed effects estimator. We are able to construct a short panel for the late 1990s using recall data on wages. Unfortunately, we do not know when the respondents joined, so we are not able to obtain a fixed

effects estimate of the overall wage premium for membership. ${ }^{4}$ However, we are able to use the panel to see if CCP members in 1999 had enjoyed higher wage growth than non-members.

\section{Empirical determinants of CCP membership}

What characteristics increase the probability of workers being CCP members? In this section we use binomial probit models to estimate the empirical determinants of an urban worker being a member. We confine the analysis to the sample of urban workers earning wages, since our 
primary focus is on the effect of membership on wages. Two sets of explanatory variables are included: personal characteristics (sex, age, ethnicity, education and city of residence) and jobrelated characteristics (occupation, ownership and industrial sectors). We estimate one model for each of the survey years, noting the rise in membership in our data from $23.5 \%$ in 1988 to $24.5 \%$ in 1995 and 26.9\% in 1999 (descriptive statistics are provided in Table A1 of the Online Appendix). Table 1 reports the results of the probit models, and Table 2 considers the predictions of the model evaluated at the means of the explanatory variables. Pair-wise Wald tests were conducted for whether the coefficients in the models changed significantly over time.

Of the personal characteristics, being male, educated and experienced all increased the probability of CCP membership in each of the surveys. The "pure" gender gap in the probability narrowed over time. Evaluating at the means of other explanatory variables, the probability of a woman being in the Party doubled from $8 \%$ in 1988 to $16 \%$ in 1999; for men, the corresponding increase was from $22 \%$ to $24 \%$. There was also a significant rise in the importance of education. For example, compare two workers (with otherwise average characteristics): one with college education (15 years) and the other with junior middle school education (9 years). In 1988, such a college graduate had a $22 \%$ predicted probability of being a member, rising to $38 \%$ in 1999 . By contrast, the prospects for a comparable worker with junior middle school were virtually unchanged at $12 \%$ in 1988 and $13 \%$ in 1999. The chances of less educated workers being members fell, ceteris paribus, in the same interval. Experience also appeared to have become increasingly important for access.

Turning to the work-related variables, factors that make Party membership more likely include being a white collar worker, being employed in an SOE and working in government administration. These findings reflect the CCP's historical role in administering many aspects of life in China. In our probit models, the single most statistically significant variable is the dummy variable for being a blue collar worker, which reduces the probability of being a member (the default being white collar). At the mean of other explanatory variables, white collar workers had a 33\% probability of being in the Party in 1999 whereas blue collar workers had only an 11\% probability. The CCP has less influence in the private sector, so recruitment there may be more difficult and offer lower benefits for members. However, there is tentative evidence that the Party 
has made progress in recruiting more members from the private sector. The models predict that the probability of membership in 1988 was $16 \%$ for those in the state-owned sector compared to $1 \%$ for those in the private sector. By 1999 , these predicted probabilities had changed to $23 \%$ and $7 \%$ respectively. ${ }^{5}$ Turning to the influence of industrial structure on the probability of membership: working in government administration is associated with the most positive impact and working in education has the most negative. Party membership is expected of workers employed in government administration, being taken as a sign of loyalty and required for performing confidential or important tasks of the state, whereas it is less required of those following professional career paths.

\section{The wage premium for CCP membership}

Communist Party members earn higher wages. In the 1988 survey, the mean daily wage for urban workers who were members was $29 \%$ higher than the mean for those workers who were not members. In the 1995 and 1999 surveys, the differential had risen to 33\%. However, not all of these differentials can be attributed to membership because membership is systematically related to characteristics such as experience and education. To isolate the influence of membership on wages, we estimate wage functions which control for the observable determinants of wages (Table 3). To allow membership to have a differential effect for workers with different characteristics, we estimate separate wage functions for members and non-members.

Whether estimating separate wage functions generates bias was explored by augmenting the wage functions with sample selectivity correction terms derived from the probits for membership. For the 1999 survey, dummy variables for parental membership of the Party are possible instruments for the selectivity corrections as they may meet two conditions. Firstly, parental membership is likely to be correlated with own membership. This may work via either demand factors (e.g. parents act as role models) or supply factors (e.g. parents vouch for one's character). Secondly, parental membership may not have strong direct effects on own wages. Empirically, the first condition is satisfied: when we augmented the probit model for 1999 in Table 1 with two dummy variables for parental Party membership, the variables were jointly significant at the $5 \%$ level. 
The second condition was examined informally by seeing whether the instruments were associated with the residuals from the wage functions (this is analogous to the formal overidentification test discussed by Deaton, 1997, p.112). We regressed the residuals from the wage functions on the instruments and could not reject the null hypothesis of no association at the $1 \%$ level of significance, although it was rejected at the $5 \%$ level for non-members (only). Given these results, we have some grounds for regarding parental Party membership as valid instruments to identify corrections for sample selectivity, although the case is stronger for members than for non-members. It is noteworthy, therefore, that these corrections were wholly insignificant - with t-ratios less than one - in both the wage function for members and that for non-members (Online Appendix Table A5 refers). These results imply that we can simply use OLS estimates of the wage functions for 1999.

Neither the 1988 nor the 1995 surveys inquired about parental membership of the CCP but information is available for all household members, including parents living with adult children. Consequently, we use parental membership as an instrument for own membership for the subsample of workers who lived with their parents .Neither of the two methods available for 1999 gives selectivity corrections that are significant at the 5\% level. In 1988 and 1995, use of the subsamples also leads to insignificant corrections for sample selectivity, with the exception of nonmembers in 1988 , for whom the selectivity correction was significantly negative. ${ }^{6}$ Finding that sample selectivity does not appear to be a significant problem in most cases gives us some confidence in relying on the results of the OLS estimates in Table 3. This approach seems preferable to working with just the sub-sample of workers still living with their parents, since that entails its own sample selectivity problem. Moreover, because Party members tend to be somewhat older and it is the younger workers who tend to still live with their parents, the subsamples include only small numbers of members.

In what follows, we focus on the wage functions estimated separately for members and nonmembers by OLS. Table 4 uses these functions to estimate the wage premia, P, for membership for different kinds of workers, using a simplified version of equation (5):

$$
P=E(\ln Y \mid M=1)-E(\ln Y \mid M=0)=\left(\mathrm{d}_{\mathrm{p}}-\mathrm{d}_{\mathrm{n}}\right)^{\prime} \mathrm{X}
$$

We obtain baseline wage premia by evaluating the sample means of the explanatory variables $X$ 
(members and non-members combined). ${ }^{7}$ Workers with average characteristics would have earned 10\% more in 1988 if they were in the Party, rising to 14\% in 1995 and 1999.

We simulate the effect on the wage of altering a given explanatory variable while holding the value of all other variables at their sample means. Generally speaking, the personal characteristics which increase the probability of CCP membership - male sex, education and experience - are associated with a lower wage premium for membership. For example, although men are more likely to be members, the CCP wage premium was only $11 \%$ for them in 1999 , compared to $16 \%$ for women. A worker with no experience (and otherwise average characteristics) would earn 32\% more in 1999 if they were a member whereas one with 20 years of experience would earn only $4 \%$ more. In the same year, a primary school graduate (with 6 years of education) would receive a $17 \%$ premium if they were in the Party compared to the $11 \%$ premium enjoyed by college graduates (15 years of education). ${ }^{8}$ Since these personal characteristics are associated with higher wages, it appears that membership may in some way substitute for such remunerative characteristics.

Quantile regression has an advantage over OLS regression in that it can show how the wage premium on CCP membership varies over the wage distribution, conditioning on the other explanatory variables. Accordingly, the wage functions in Table 3 were augmented with a dummy variable for CCP membership and estimated using quantile regressions on pooled (members and non-members) samples of workers (Table 4). The relevant comparison is of quantile 25 ( $25^{\text {th }}$ from the bottom of the conditional wage distribution) and quantile 75 . Insofar as the omitted variables captured by the residual wage represent unobserved personal characteristics such as "ability", we expect the quantile regressions to standardize for ability: the lower quantile should represent workers of lower ability than does the higher quantile. In both 1995 and 1999 the coefficient on CCP membership for quantile 25 exceeds that on quantile 75 (by 4.4 and 3.5 percentage points respectively). Membership is more valuable for workers of lower than average higher ability. By rewarding less able workers more, membership is again substituting for other remunerative characteristics. The rise in the coefficient which occurred over time was greater for quantile 25 than for quantile 75 (increasing by 5.6 and 3.2 percentage points respectively). Thus, CCP membership became absolutely more valuable generally but relatively more valuable for 
workers of lower ability.

Being a white collar worker - like being educated or experienced - is another remunerative characteristic that increases the chances of membership but is associated with a lower wage premium. In 1999, blue collar workers would earn $21 \%$ more if they were in the Party; white collar workers would earn only $7 \%$ more. The coefficient on the dummy variable for being a blue collar worker in Table 3 suggests that such members have been protected from the widening occupational wage differentials since 1988 experienced by non-members. Pair-wise Wald tests show that, at the $5 \%$ level, this variable has significantly different coefficients for members and non-members in both 1995 and 1999.

The coefficients on the dummy variables for the ownership and industrial sector of the worker's enterprise do not generally differ significantly as between members and non-members. This is perhaps surprising since it implies that membership does not bring significantly greater returns in the SOE sector than in the collective or private sectors. The main exception is government administration. In 1988, this variable had a significantly smaller coefficient for members than for non-members, implying a smaller premium (by 5\%) for civil servants than for other kinds of workers. However, in 1999, the reverse was true - the variable had a significantly larger coefficient for members and the CCP wage premium for government administration workers stood at $20 \%$.

In summary, we find little evidence to support the hypothesis that the characteristics that make it likely that workers join the $\mathrm{CCP}$ also tend to raise the wage premium for membership. Although membership appears to pay more for those working in government administration and such workers are more likely to join the Party, the balance of the evidence demonstrates contrary patterns. Ceteris paribus, men are more likely to join, but the premium is lower for them. Similarly, more educated and experienced workers are more likely to be members but the returns to education and experience are lower for members. Blue-collar workers are the least likely to be members, yet they are the occupational category that appears to benefit the most from membership. Some characteristics that raise the probability of membership - such as employment in an SOE - appear to have no independent effect on the wage premium for membership. As 
suggested in Section 3, this pattern seems consistent with the notion that membership is primarily determined by screening rather than by individual demand for membership. The Party prefers to recruit people who will keep the system going; with marketisation, these are increasingly those with characteristics that are rewarded through higher wages. However, such people do not necessarily benefit more than others from being members. If the value of membership depends partly on scarcity, then among groups of workers where membership is relatively common, the average benefit of membership may be lower. For example, among particular groups of workers, there may be a given number of posts of leadership or responsibility that attract higher wages and which Party members are more likely to be given. If there are more members within a group of workers competing for those posts, there will be less chance that any one member will be successful - lowering the average wage premium for CCP membership.

\section{The CCP wage premium during retrenchment}

The main potential methodological problem with the cross-sectional approach is that the endogeneity of membership may give rise to biases in OLS estimates. Using techniques to control for sample selectivity, we have argued that such biases are not a significant problem with our data. However, an alternative approach is to use fixed effects estimates derived from panel data on individuals. If CCP members have unobserved characteristics that make them more productive and hence higher paid, then these characteristics should be controlled for as part of the individual-level fixed effect.

The 1999 survey included recall questions on wages in the previous four years. We can use these data to construct a retrospective panel on wages from 1995 to 1999. Unfortunately, most of the potential explanatory variables (excluding experience) can appear only as timeinvariant variables in the analysis. For example, we do not have data on when people joined the CCP and so cannot estimate the overall membership premium based on wages before and after joining. However, we can still use a fixed effects model to explore how the wages of members in 1999 have grown compared to those who were not members in 1999. This will provide some insight into the changing fortunes of a given cohort of workers during the years 
1995-99, which was a period of large scale retrenchment of labour.

Table 5 reports the results of the fixed effects estimates, estimated separately for nonretrenched and retrenched workers. We classify workers as retrenched if they were retrenched at any time between 1992 and 1999/2000; hence this classification is time-invariant. To estimate the possible effects of re-employment on wages, we include a time-varying dummy variable for being re-employed. Since the wage structure may be different for the reemployed, we interact this dummy variable with variables for personal characteristics and also the year dummies. ${ }^{9}$

For the majority of workers - those who have not been retrenched - the interaction term between the dummy variable for 1999 and that for membership is statistically significant with a coefficient of 0.059: compared to 1995, the premium such workers enjoyed over others rose by 6 percentage points. Inspection of the interactions between the CCP dummy and dummies for intervening years indicates that the rise of the premium was sustained and incremental during the period. Since this result is generated by a fixed effects estimate, the rise in the premium cannot be due to a change in the composition of membership, arising, for example, from the Party's trying to recruit more entrepreneurial members.

It has previously been shown using the 1999 survey that CCP members had a lower probability of being retrenched, ceteris paribus, but equal probabilities of re-employment conditional on being retrenched (Appleton et al., 2002). In the fixed effects wage function for retrenched workers, the interactions between the dummy for membership in 1999 and the year dummies are near zero and statistically insignificant. That is to say, those CCP members in 1999 who had been retrenched did not fare any better than non-members. Moreover, the interaction between the dummy for membership in 1999 and that for re-employment is significantly negative. The overall effect of re-employment on wages cannot be readily evaluated since there are several interaction terms (not shown) between re-employment and other determinants of wages. At the mean of all explanatory variables, the overall effect is positive: retrenched workers are predicted to earn more if re-employed than they would have if they had kept their old jobs. This is contrary to the more common finding in other countries 
that unemployment may "scar" a worker, leading to lower wages in future. However, a Party member with other personal characteristics equal to the mean for the re-employed would earn $21 \%$ less when re-employed in a new job than they would have earned had they remained in their old job. This implies that the wage premia that members enjoy are tied to the jobs they held in 1995 and do not survive retrenchment and re-employment. This casts some doubt on the explanation of the $\mathrm{CCP}$ wage premium as reflecting either higher productive ability or network advantages in finding good jobs in the emerging labour market.

\section{Conclusions}

There are great difficulties in attributing causation to the associations found in our crosssection data and even our panel data. For instance, some of the determinants of CCP membership might themselves be influenced by CCP membership, and CCP membership might represent other, unobserved determinants of wages. Although we have addressed these issues wherever possible, our results should be regarded as suggestive of causal processes rather than as establishing them. Nevertheless, the study has uncovered a hitherto unexplored and interesting phenomenon which deserves to be explained. Accordingly, we provide our tentative interpretation.

The economics of Communist Party membership in China is curious in several respects. A first paradox is that both the number of members and the size of the wage premium for membership appear to have risen during economic transition. With the move away from a command economy, one might expect membership to have become less important in determining a worker's wages and general welfare. Such a reduction in the economic benefits would lower the demand for membership and lead to a fall in recruitment. However, the reverse has been observed in China during the transition. Membership has risen and the rising wage premium for members estimated in this paper helps us understand this phenomenon. A comparison of urban household surveys shows that the "pure" wage premium for membership has risen from $10 \%$ in 1988 to $14 \%$ in 1999 . The two trends of a rising wage premium and a rising membership are consistent with a demand-side explanation, whereby individuals invest 
in Party membership as a form of political capital. In terms of the aggregate time series evidence, a rise in the monetary benefits might be said to have induced an increase in membership. To some extent, the rise in the wage premium may be a disequilibrium phenomenon. If the Party fully accommodates the increase in demand, the greater initial rents will induce more people to join the Party, lowering the average return.

However, such a simple demand side explanation seems inadequate to explain a second paradox observed in our cross-sections - that the people who are the most likely to join the Party receive the lowest benefit. In most cases, worker characteristics that raise the likelihood of a worker being in the Party also reduce the wage premium for membership. Education, experience, male sex and being in a white-collar occupation all significantly raise the probability of a worker being a member. These characteristics are also rewarded with higher wages, for both members and non-members, but appear to be more rewarded for nonmembers than for members. In general, therefore, one cannot explain the higher rates of membership among certain groups by a higher expected benefit. If anything, membership rates are higher when the premia are lower.

This second paradox suggests that membership is supply-constrained rather than demandconstrained: the cross-sectional patterns are determined by the Party's screening decisions, not by individuals' demand to join. Although the Party has allowed the number of members to rise, it has nevertheless rationed places. The rationing criteria reflect the personal characteristics that are valuable for the CCP's political and economic objectives. As a result, there may be a scarcity value to membership for workers with less favoured characteristics. For example, membership leads to higher wages partly through providing increased access to a certain number of responsible posts. Securing these posts may provide more of an increase in wages for a person with otherwise low-return characteristics than for one with high-return characteristics. Hence, membership may partly substitute for experience or education in obtaining certain posts. This effect may be reinforced if competition for some posts is limited to people of similar characteristics. For example, a factory floor supervisor may have to be a blue-collar rather than a white-collar worker. If there are relatively few Party members among the blue-collar workers, then the likelihood of any one member obtaining a desired 
supervisory post will be higher and thus the benefits of membership greater.

What explains the rise in the wage premium for Party members? We found no evidence that it reflects an increase in the average ability of members or an increase in the returns to ability. When we used parental Party membership as an instrument to correct for the selectivity of own membership, those recruited into the CCP appeared not to have higher unobserved productivity. Recall data on wages prior to 1999 showed increases in the wage premium even after controlling for unobserved time-invariant individual characteristics. Our quantile regression analysis indicated that the wage premium on membership increased more for low ability than for high ability workers. Those members who were unlucky enough to be retrenched after 1995 experienced wage scarring, unlike non-members. This implies that the wage premium was job-specific, rather than reflecting generally higher productive ability or social capital: when turned into "outsiders" from their enterprises, Party members seem illequipped to flourish in a harsher, more competitive environment.

We tentatively conclude that the rise in the wage premium for members - much like the rise in the gender gap in wages - may be a by-product of the general increase in wage differentials during the transition from planning. Whereas before, income inequalities were compressed for political reasons, under reform, enterprises have more discretion in setting wages. This may give more room for discriminatory, as well as productive, factors to work in determining wages. CCP members may more be able to secure personal benefits from their political status during the transition from planning. Although the rise in the wage premium could have been fortuitous rather than planned, the Party may well have had an interest in allowing it to happen. If the non-economic benefits of membership diminish - as ideology and status become less important - a higher premium may be necessary to keep up recruitment and membership, and so maintain Party control.

What are the implications of the rise in the wage premium for Party members during reform? At face value, it contradicts Nee's market transition hypothesis of a rise in the return to productive characteristics and a fall in the returns to unproductive ones. This need not be a concern on efficiency grounds if the rise in the wage premium could actually be explained in 
terms of the rewards to unobserved productivity of Party members. However, some doubt is cast on this explanation by our evidence that the rising premium does not appear to be explained by either an increase in the average ability of members or an increase in the returns to ability. The rise in the premium may indicate a limitation in the extent to which the Chinese labour market has become competitive.

In distributional terms, an increasing wage premium would seem to be undesirable. Not only is it an unjustified horizontal inequality but it is also likely to worsen vertical inequalities since CCP members typically have characteristics which are economically rewarded in their own right. However, the political implications of these distributional changes are less clearcut. One could take a sanguine view and argue that growing benefits for Party members are desirable because they help to ensure that the reforms are self-sustaining. If members do well during the transition, they will continue to support the reforms. Nonetheless, if these benefits are viewed as unjustified, they risk discrediting both the Party and the reforms. 


\section{References}

Appleton, Simon, John Knight, Lina Song and Xia, Qingjie (2002) Labour retrenchment in China: Determinants and consequences. China Economic Review, 14 (2-3): 252-75.

Appleton, Simon, John Knight, Lina Song and Xia, Qingjie (2004) Contrasting paradigms: Segmentation and competitiveness in the formation of the Chinese labour market, Journal of Chinese Economic and Business Studies, 2(3), pp. 185-205.

Ashenfelter, Orley and Krueger, Alan (1994) Estimates of the economic return to schooling from a new sample of twins. The American Economic Review, 84(5), pp. 1157-73.

Bian, Yanjie and Logan, John R. (1996) Market transition and persistence of power: the changing stratification system in urban China. American Sociological Review 61, pp. 739-58.

Bian, Yanjie, Shu, Xiaoling and Logan, John R. (2001) Communist Party membership and regime dynamics in China. Social Forces, 79, pp.805-41.

Bishop, John A., Feijun Luo and Wang, Fang (2005) Economic transition, gender bias, and the distribution of earnings in China. Economics of Transition 13 (2), pp.239-59.

Deaton, Angus (1997) The analysis of household surveys. (Baltimore: Johns Hopkins University Press).

Djilas, Milovan (1957) The new class: an analysis of the Communist system in power (New York: Praeger).

Groves, Theodore, Yongmiao Hong, John McMillan and Barry Naughton (1995) China's evolving managerial labour market. Journal of Political Economy 103(4), pp. 873-92.

Guo, Gang (2002) Party recruitment and political participation in Mainland China. $\mathrm{PhD}$, Political Science, University of Rochester.

Halvorsen, Robert and Raymond, Palmquist (1981) The interpretation of dummy variables in semilogarithmic equations. American Economic Review 70(3), pp. 474-475.

Heckman, James (1979) Sample selection bias as a specification error. Econometrica 47, pp. 15361.

Knight, John and Lina Song (2003) Increasing urban wage inequality in China. Economics of Transition, 11 (4), pp. 597-619.

Lam, Kit-Chun Joanna (2003) Earnings advantages of Party members in urban China. Business Research Centre Working Paper, Department of Economics, Hong Kong Baptist University. 
Li, Bobai and A. G. Walder (2001) Career advancement as party patronage: sponsored mobility into the Chinese administrative elite, 1949-1996. The American Journal of Sociology 106(5) pp. 1371-1408.

Li, Hongbin, Pak Wai Liu, Ning Ma and Junsen Zhang (2007) Economic returns to Communist Party membership: evidence from Chinese twins. Economic Journal 117 (553), pp.1504-1520.

Liu, Zhiqiang (2003) The economic impact and determinants of investment in human and political capital in China. Economic Development and Cultural Change 51, pp. 823-49.

Morduch, Jonathan; and Sicular, Terry (2000) Politics, growth, and inequality in rural China: does it pay to join the Party? Journal of Public Economics 77, pp.331-356.

Nee, V. (1989) A theory of market transition: from redistribution to markets in state socialism, American Sociological Review 54 (5), pp.663-81.

Rosenthal, Elisabeth (2002) China's Communists try to decide what they stand for. New York Times, 1 May.

Walder, A. G. (1995) Career mobility and the Communist political order. American Sociological Review 57(3), pp.524-39.

Wu, Xiaogang (2006) Communist cadres and market opportunities: entry into selfemployment in China, 1978-1996. Social Forces 85(1), pp. 389-411.

Xie. Yu and Hannum, Emily (1996) Regional variation in earnings inequality in reform-era urban China. The American Journal of Sociology 101(4), pp.950-92 
Table 1: Probits models for CCP membership, selected variables

\begin{tabular}{|c|c|c|c|c|}
\hline & & 1988 & 1995 & 1999 \\
\hline \multicolumn{2}{|l|}{ Constant } & $\begin{array}{c}-2.883 \\
(25.16) * * *\end{array}$ & $\begin{array}{c}-3.082 \\
(24.74) * * *\end{array}$ & $\begin{array}{c}-3.458 \\
(18.51)^{* * *} \\
\end{array}$ \\
\hline \multicolumn{2}{|l|}{ Male sex } & $\begin{array}{c}0.628 \\
(23.29) * * *\end{array}$ & $\begin{array}{c}0.493 \\
(16.66) * * *\end{array}$ & $\begin{array}{c}0.361 \\
(9.01)^{* * *} \\
\end{array}$ \\
\hline \multicolumn{2}{|l|}{ Experience } & $\begin{array}{c}9.62 \mathrm{E}-02 \\
(18.14)^{* * *}\end{array}$ & $\begin{array}{c}0.089 \\
(14.79)^{* * *}\end{array}$ & $\begin{array}{l}6.96 \mathrm{E}-02 \\
(8.21)^{* * *}\end{array}$ \\
\hline \multicolumn{2}{|c|}{ Experience squared } & $\begin{array}{c}-1.06 \mathrm{E}-03 \\
(10.04) * * *\end{array}$ & $\begin{array}{c}-0.001 \\
(7.55) * * *\end{array}$ & $\begin{array}{c}-4.22 \mathrm{E}-04 \\
(2.33)^{* *}\end{array}$ \\
\hline \multicolumn{2}{|c|}{ Full-time education (years) } & $\begin{array}{c}0.069 \\
(11.48)^{* * *}\end{array}$ & $\begin{array}{c}0.090 \\
(15.58)^{* * *}\end{array}$ & $\begin{array}{c}0.135 \\
(14.03)^{* * *}\end{array}$ \\
\hline \multirow{2}{*}{$\begin{array}{l}\text { Industry } \\
\text { (default variable } \\
\text { is } \\
\text { manufacturing) }\end{array}$} & Education & $\begin{array}{c}-0.233 \\
(4.76)^{* * *}\end{array}$ & $\begin{array}{c}-0.130 \\
(2.24)^{* *}\end{array}$ & $\begin{array}{c}-0.160 \\
(1.98)^{* *}\end{array}$ \\
\hline & Government & $\begin{array}{c}0.674 \\
(15.06)^{* * *} \\
\end{array}$ & $\begin{array}{c}0.552 \\
(11.99) * * *\end{array}$ & $\begin{array}{c}0.448 \\
(6.23)^{* * *} \\
\end{array}$ \\
\hline \multicolumn{2}{|c|}{ Number of observations } & 17733 & 12245 & 6281 \\
\hline \multicolumn{2}{|l|}{ Log-likelihood } & -6563.5 & -5210.8 & -2777.0 \\
\hline \multicolumn{2}{|c|}{ Restricted log-likelihood } & -9662.7 & -6818.8 & -3656.6 \\
\hline \multicolumn{2}{|c|}{ Pseudo R-squared } & 0.3207 & 0.2358 & 0.2406 \\
\hline
\end{tabular}

Notes: (1) Dummy variables for regions, for "other occupation", "other ownership" and "other industry" are also controlled for but not report for brevity.

(2) T-ratios are in brackets. *** denotes statistical significance at $1 \%$ level and below, $* *$ at $5 \%$, and $*$ at $10 \%$ level.

(3) In this, and subsequent, tables, only those variables that are discussed in the text are reported in the table; the full results are shown in Table A2 of the Online Appendix. 
Table 2: Predicted probabilities of CCP membership and predicted CCP wage premium (percentages), selected variables

\begin{tabular}{|c|c|c|c|c|c|c|}
\hline & \multicolumn{3}{|c|}{ (a) Predicted probability CCP member } & \multicolumn{3}{|c|}{ (b) Predicted CCP wage premium } \\
\hline & 1988 & 1995 & 1999 & 1988 & 1995 & 1999 \\
\hline Baseline & 14 & 18 & 21 & 10 & 14 & 14 \\
\hline Male & 22 & 25 & 26 & 9 & 11 & 11 \\
\hline Female & 8 & 12 & 16 & 12 & 17 & 16 \\
\hline Experience of 0 years & 1 & 1 & 2 & 34 & 25 & 32 \\
\hline Experience of 10 years & 5 & 6 & 7 & 15 & 23 & 10 \\
\hline Experience of 20 years & 17 & 18 & 19 & 6 & 12 & 4 \\
\hline Experience of 30 years & 30 & 31 & 34 & 5 & 12 & 6 \\
\hline Education of 0 years & 4 & 3 & 1 & 23 & 28 & 21 \\
\hline Education of 6 years & 8 & 9 & 6 & 15 & 20 & 17 \\
\hline Education of 9 years & 12 & 15 & 13 & 12 & 16 & 15 \\
\hline Education of 12 years & 17 & 22 & 24 & 9 & 12 & 13 \\
\hline Education of 15 years & 22 & 30 & 38 & 5 & 8 & 11 \\
\hline Ownership & & & & & & \\
\hline State-owned & 16 & 20 & 23 & 9 & 13 & 15 \\
\hline Private enterprises & 1 & 3 & 7 & -20 & 50 & 9 \\
\hline Occupation & & & & & & \\
\hline White collar & 29 & 28 & 33 & 9 & 9 & 7 \\
\hline Blue collar & 7 & 9 & 11 & 11 & 20 & 21 \\
\hline Industry & & & & & & \\
\hline Education & 9 & 14 & 14 & 10 & 9 & 11 \\
\hline Government & 34 & 34 & 32 & 5 & 8 & 20 \\
\hline
\end{tabular}

Notes:
(1) All results evaluated at the mean of the other explanatory variables.
(2) Probabilities generated from Table 1, wage premia from Table 3.
(3) The full results are shown in Table A3 of the Online Appendix. 
Table 3

Wage functions for 1988, 1995 and 1999 for CCP members and non-members, selected variables

\begin{tabular}{|c|c|c|c|c|c|c|}
\hline & \multicolumn{2}{|c|}{1988} & \multicolumn{2}{|c|}{1995} & \multicolumn{2}{|c|}{1999} \\
\hline Male & $\begin{array}{c}\text { Non-CP } \\
0.102 \\
(14.54) * * *\end{array}$ & $\begin{array}{c}\mathrm{CP} \\
0.073 \\
(5.16)^{* * *}\end{array}$ & $\begin{array}{c}\text { Non-CP } \\
0.144 \\
(10.26)^{* * *}\end{array}$ & $\begin{array}{c}\mathrm{CP} \\
0.087 \\
(3.84)^{* * *}\end{array}$ & $\begin{array}{c}\text { Non-CP } \\
0.195 \\
(10.35 * * *\end{array}$ & $\begin{array}{c}\mathrm{CP} \\
0.153 \\
(4.86)^{* * *}\end{array}$ \\
\hline Experience & $\begin{array}{c}4.96 \mathrm{E}-02 \\
(36.54) * * *\end{array}$ & $\begin{array}{l}3.01 \mathrm{E}-02 \\
(9.58)^{* * * *}\end{array}$ & $\begin{array}{l}5.987 \mathrm{E}-02 \\
(20.91)^{* * * *}\end{array}$ & $\begin{array}{l}5.10 \mathrm{E}-02 \\
(9.29)^{* * * *}\end{array}$ & $\begin{array}{l}4.71 \mathrm{E}-02 \\
(12.29) * * *\end{array}$ & $\begin{array}{l}3.016 \mathrm{E}-02 \\
(4.67)^{* * * *}\end{array}$ \\
\hline $\begin{array}{l}\text { Experience squared } \\
\text { term }\end{array}$ & $\begin{array}{l}-7.30 \mathrm{E}-04 \\
(23.05) * * *\end{array}$ & $\begin{array}{l}-3.56 \mathrm{E}-04 \\
(5.82) * * *\end{array}$ & $\begin{array}{l}-1.052 \mathrm{E}-03 \\
(15.21)^{* * *}\end{array}$ & $\begin{array}{l}-8.82 \mathrm{E}-04 \\
(7.71)^{* * *}\end{array}$ & $\begin{array}{l}-8.79 \mathrm{E}-04 \\
(10.08)^{* * * *}\end{array}$ & $\begin{array}{c}-4.986 \mathrm{E}-04 \\
(3.66) * * *\end{array}$ \\
\hline $\begin{array}{l}\text { Full-time education } \\
\text { (years) }\end{array}$ & $\begin{array}{c}0.033 \\
(16.32) * * *\end{array}$ & $\begin{array}{c}0.024 \\
(9.53)^{* * * *}\end{array}$ & $\begin{array}{c}0.036 \\
(12.42)^{* * * *}\end{array}$ & $\begin{array}{c}0.025 \\
(7.33)^{* * * *}\end{array}$ & $\begin{array}{c}0.041 \\
(8.96)^{* * *}\end{array}$ & $\begin{array}{c}0.035 \\
(6.18)^{* * * *}\end{array}$ \\
\hline \multicolumn{7}{|c|}{ Occupation (default variable is white collar) } \\
\hline Blue collar & $\begin{array}{c}-0.057 \\
(6.47) * * *\end{array}$ & $\begin{array}{c}-0.041 \\
(2.21)^{* *}\end{array}$ & $\begin{array}{c}-0.165 \\
(9.74)^{* * *}\end{array}$ & $\begin{array}{c}-0.066 \\
(1.99)^{* *}\end{array}$ & $\begin{array}{c}-0.171 \\
(7.45)^{* * *}\end{array}$ & $\begin{array}{l}-0.044 \\
(1.02)\end{array}$ \\
\hline \multicolumn{7}{|c|}{ Industry (default variable is manufacturing) } \\
\hline Government & $\begin{array}{c}-0.060 \\
(3.72) * * *\end{array}$ & $\begin{array}{c}-0.120 \\
(7.71)^{* * * *}\end{array}$ & $\begin{array}{c}0.082 \\
(3.35)^{* * *}\end{array}$ & $\begin{array}{l}0.027 \\
(1.10)\end{array}$ & $\begin{array}{c}0.241 \\
(6.37)^{* * * *}\end{array}$ & $\begin{array}{c}0.338 \\
(8.05)^{* * *}\end{array}$ \\
\hline No. of observations & 13571 & 4162 & 9244 & 3001 & 4592 & 1689 \\
\hline Adjusted R-squared & 0.364 & 0.247 & 0.273 & 0.298 & 0.283 & 0.264 \\
\hline
\end{tabular}

Notes: (1) Dependent variable is log hourly wage; T-ratios are in brackets.

(2) $* * *$ denotes statistical significance at $1 \%$ level, $* *$ at $5 \%$ and $*$ at $10 \%$ level

(3) The full results are shown in Table A5 of the Online Appendix. 
Table 4: Coefficients on CCP dummy in quantile wage regressions

\begin{tabular}{|c|c|c|c|c|}
\hline & 1988 & 1995 & 1999 & $\mathbf{1 9 9 9}$ minus 1988 \\
\hline Quantile 25 & 0.051 & 0.073 & 0.107 & $\mathbf{0 . 0 5 6}$ \\
& $(6.39)^{* * *}$ & $(5.08)^{* * *}$ & $(4.59)^{* * *}$ & 0.072 \\
Quantile 75 & 0.048 & 0.029 & $(4.02)^{* * *}$ & 0.024 \\
Quantile 25 minus & $(6.21)^{* * *}$ & $(2.15)^{* * *}$ & 0.035 & $\mathbf{0 . 0 3 2}$ \\
75 & 0.003 & 0.044 & $\mathbf{6 2 8 1}$ & \\
No. of observations & $\mathbf{1 7 7 3 3}$ & $\mathbf{1 2 2 4 5}$ & & \\
\hline
\end{tabular}

Notes:

(1) The dependent variable is log hourly wage

(2) T-ratios are in brackets. *** denotes statistical significance at the $1 \%$ level

(3) Fuller results are shown in Table A6 of the Online Appendix 
Table 5: Fixed effects estimates of changes in wages function coefficients, 1995-1999, selected variables

\begin{tabular}{|c|c|c|c|c|c|c|}
\hline & \multicolumn{3}{|c|}{ Non-retrenched } & \multicolumn{3}{|c|}{ Retrenched } \\
\hline & $\begin{array}{l}\text { Coefficien } \\
t\end{array}$ & T-ratio & & Coefficient & T-ratio & \\
\hline \multicolumn{7}{|l|}{ Year dummies: } \\
\hline 99 & 0.370 & 7.84 & $* * *$ & 0.037 & 0.12 & \\
\hline 98 & 0.283 & 6.20 & $* * *$ & 0.177 & 1.06 & \\
\hline 97 & 0.129 & 2.91 & $* * *$ & 0.113 & 0.73 & \\
\hline 96 & 0.000 & -0.00 & & 0.055 & 0.37 & \\
\hline \multicolumn{7}{|l|}{ Interactions with year dummies: } \\
\hline Party member*99 & 0.059 & 4.25 & $* * *$ & 0.122 & 0.94 & \\
\hline Party member*98 & 0.055 & 3.95 & $* * *$ & -0.001 & -0.02 & \\
\hline Party member*97 & 0.039 & 2.76 & $* * *$ & 0.066 & 1.01 & \\
\hline Party member*96 & 0.010 & 0.70 & & -0.013 & -0.21 & \\
\hline $\begin{array}{l}\text { Dummy variable for re-employment (time } \\
\text { varying) }\end{array}$ & & & & 0.842 & 2.93 & $* * *$ \\
\hline \multicolumn{7}{|c|}{ Interactions with a time varying dummy variable for re-employment: } \\
\hline Party member*re-employment & & & & -0.319 & -2.83 & $* * *$ \\
\hline Number of observations & \multicolumn{3}{|c|}{26938} & \multicolumn{3}{|c|}{4639} \\
\hline R-squared across individuals & \multicolumn{3}{|c|}{0.1421} & \multicolumn{3}{|c|}{0.0675} \\
\hline
\end{tabular}

Notes:

(1) $* * *$ denotes statistical significance at $1 \%$ level, $* *$ at $5 \%$ and $*$ at $10 \%$ level.

(2) The full results are shown in Table A7 of the Online Appendix. 


\section{Notes}

\footnotetext{
${ }^{1}$ The authors are grateful to the CCK Foundation and DfID (under Escor grant R7526) for supporting the research and for comments received from referees and from seminars and conferences at CERDI-CNRS, Université d'Auvergne, and the universities of Gothenburg, Nottingham and Oxford.

${ }^{2}$ For example, from their sample of 2,096 people in Shanghai and Tianjin in 1993, $18 \%$ of whom had joined the Party, Bian et al. (2001) found no-one who had withdrawn from membership.

${ }^{3}$ This is pithily expressed in two quotes from CCP members cited by Rosenthal (2002): "What does the Communist Party stand for now? Nothing. Stability maybe. But really no ideals at all." and "There is almost noone now who believes in the Party for its ideals."

${ }^{4}$ However, information on income before and after joining the Party may not be informative: people do not leave the CCP (so reducing 'events') and the economic benefits may flow only some time after joining.

${ }^{5}$ The evidence is tentative: Wald tests show that the change is significant only at the $11 \%$ level.

${ }^{6}$ This result implies that there was a positive correlation between the unobservables determining wages for nonmembers and the unobservables determining CCP membership.

${ }^{7}$ Strictly speaking, $P$ is an approximation of the percentage wage differential; Table 4 uses the transformation $\exp (P)-1$ (see Halvorsen and Palmquist, 1981).

${ }^{8}$ Pair-wise Wald tests indicate that almost all of these differences are significant at the $5 \%$ level.

${ }^{9}$ The results of this analysis are reported in Appleton et al.,2004.
} 